\title{
Collaborative determination of flood shelter and evacuation route in a flooded area in Rumbai Subdistrict, Pekanbaru
}

\author{
Bambang Sujatmoko ${ }^{1^{*}}$, Rangga Fernando ${ }^{1}$, and Andy Hendri ${ }^{1}$ \\ ${ }^{1}$ Civil Engineering Department, University of Riau, 28293 Pekanbaru, Indonesia
}

\begin{abstract}
Floods in Pekanbaru City have often hit the region along the Siak river, including the Rumbai subdistrict. Disasters such as floods have detrimental impacts on society, including a massive loss of lives. However, several strategies can minimize the impacts of flooding, including making a plan evacuation route mapping with Geographic Information Systems (GIS). This is a planning-based analysis of data using the algorithm djikstra for result pathways for efficient and effective evacuation. The evacuation routes involve seven simulation parameter modeling, specifically flood, length path, wide roads, road conditions, road materials, presence or absence of bridges, and the road's direction. These parameters are processed using algoritma djikstra to generate the appropriate evacuation routes based on study area conditions. The analysis focuses on one evacuation route in Palas and the other six in Sri Meranti Village. The routes in Palas Village lead to the evacuation place of the Al-Jihad Mosque, while those in Sri Meranti Village heads to Al-Ikhlas Mosque, MDA Aula Rumbai, Nurul Haq Mosque, M Nurul Mosque, vacant land, and Stadium Parking Area.
\end{abstract}

\section{Introduction}

The high rainfall in the watershed upstream of Siak and Pekanbaru has caused floods in some areas within Pekanbaru city. According to [1], Siak riverbanks traverse some of the towns vulnerable to flooding, including subdistrict Rumbai, Rumbai Pesisir, Payung Sekaki, Senapelan, Limapuluh Kota, and Tenayan Raya, as well as the southern section in the subdistrict Tampan, Marpoyan Damai, and Bukit Raya.

The flood caused harm, such as damaging the various types of structures, including bridges, cars, buildings, sewer systems, roads, and canals, leading to significant material losses. The communities likely to be affected should be moved to safe areas. The absence of a flood evacuation line route is attributed to the communities' ignorance. There is a need to design or plan before the onset of catastrophic flooding to minimize the possible losses to anticipate these problems. A study of the area often hit by floods is necessary to minimize the impacts. This involves examining how long and wide the floodaffected area is to draw the evacuation path planning appropriately, effectively, and efficiently. The preparation of a map of the evacuation line in a flooded area at district Rumbai using GIS application is essential for the Government to take the right policy in handling flooding. This study examines the road network as an alternative to flood evacuation path and specifies the area ideal for evacuation (Flood Shelter). This research is beneficial in several ways, such as suggesting alternative evacuation routes and an effective evacuation place for affected residents. The results can be used to anticipate or minimize casualties in the event of a disaster. The study also provides information about the path that can be traversed.

\section{Literature Review}

\subsection{Disaster Mitigation}

Mitigation measures are structural and non-structural efforts taken to limit the adverse impacts of natural hazards, environmental degradation, and technology dangers. Structural mitigation includes infrastructure development Sabo, levee, or early warning detection tool. Contrastingly, non-structural include training and capacity building in the Community [2].
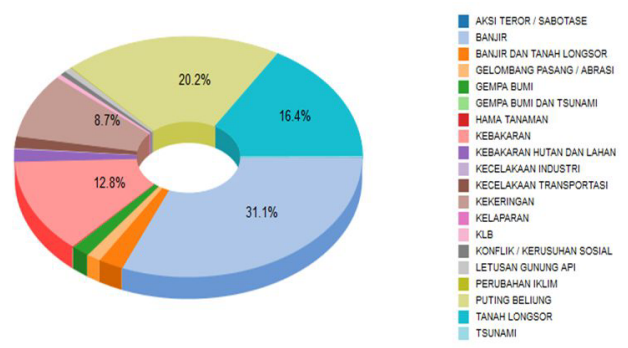

Fig.1. Amount of Disaster.

* Corresponding author: b.sujatmoko@eng.unri.ac.id 
Disaster mitigation refers to efforts to reduce the impact of a disaster before its occurrence, including preparedness and long-term actions to reduce risk in the affected areas. Mitigation involves several activities, such as creating disaster-prone area maps, putting up signs warning of the disaster-prone region's dangers, setting up a temporary shelter in evacuation routes, and moving the community to Flood

According to data from the national disaster mitigation agency (BNPB), 31.1\% of first ranking floods have happened in Indonesia, as shown in Fig.1. The western part of the country is often affected by floods because of high rainfall compared to the central and eastern parts [3].

\subsection{Modeling Simulation of River Flood}

The depth of the flood simulation is retrieved based on the region's morphology in the form of contour data of DEM (Digital Elevation Model), the spatial resolution of $20 \mathrm{~m}$ contours. This is data in the form of imaginary lines on the ground connecting points with equal elevation or contour lines. In general, continuous are lines on the top of a map showing areas with the same height. Mapping the spread of Flood inundation in Rumbai is made through iteration using the nearest neighborhood operation. Iteration is a type of folder calculation and involves repeated mathematical operations in a row using a calculation result as input to subsequent calculations. The calculation is carried out through pixel per pixel.

\subsection{Determination of the Flood Evacuation Place}

Determination of Evacuation place is one of the efforts made to ensure the safety of the affected communities ([4], [5]). For the evacuation process to run smoothly, there is a need for support, including community involvement. According to Mei et al. (1995), the evacuation process can be complex when the affected communities cannot perform the evacuation. In the planning of evacuation places (flood shelters), initial steps undertaken include identifying the location of the existing conditions in the form field when the flood is not interrupted. According to research [5], flood shelter has some basic characteristics, including being flood free, Washing amenities and Latrines (PUBLIC) should match the number of refugees, the height of the building evacuation of the higher building evacuation is getting an excellent place for evacuation, spacious building to accommodate the capacity of refugees, and accessibility from the gathering point to the evacuation place.

\subsection{Determination of The Evacuation Line}

Evacuation is a route path that leads the community flood victims to safer places. A disaster evacuation line is a form of fundamental information needed in disaster-prone areas, such as floods. Evacuations need Government and public preparedness in flood-prone areas as listed in Act No. 24 of disaster relief [3].
Some of the principles for determining flood evacuation [5] include (1) evacuation paths designed away from the flow of the river, (2) recommended evacuation Lines do not cross the River/Bridge, (3) In the more densely populated areas, evacuation lines designed in the form of a block system limited by the flow of the River, where the movement blocks are not mixed to avoid congestion, and (4) each line of the evacuation need signs for refugees heading to a safe place.

\subsection{Geographic Information Systems (GIS)}

GIS can be interpreted literally as a component of hardware, software, geographical data, and human resources treated to manage data and display an information system. Understanding managing information involves taking, saving, repairing, renewing, manipulating, integrating, and analyzing data.

GIS is essential in handling and data analysis based on geographical location. It works based on integrating 4 components, including hardware, software, data management, and the user. A space scope process was conducted on GIS [6]. Spatial analysis function based on a GIS capability can also be identified from reviewing the functions that can be performed.

\subsection{Djikstra's Algorithm Method}

Implementing the algorithm invented by Dijkstra's shortest path is complex and challenging, hence the need to look for a more efficient one. Suppose $\mathrm{G}$ is a directional graph with labeled points $\mathrm{V}(\mathrm{G})=\{\mathrm{v} 1, \mathrm{v} 2, \ldots, \mathrm{vn}\}$, and the shortest path is searched from v1 to vn, Dijkstra's algorithm starts from the point $\mathrm{v} 1$. In the iteration, the algorithm will look for a one-point number weighing from point 1 to the smallest. Graf is defined as the set of pairs $(\mathrm{V}, \mathrm{E})$ written with the notation $\mathrm{G}=(\mathrm{V}, \mathrm{E})$, which in this case is the set $\mathrm{V}$ of vertices, not empty nodes (vertices or nodes), while $\mathrm{E}$ is the set of slides (edges or arcs) connecting a pair of vertices [11].

\section{Methodology}

\subsection{Data Collection}

The first step of conducting this research is gathering data, which was obtained from (1) Administrative Data and colonization of Pekanbaru published statistics Indonesia (BPS) Pekanbaru [7], (2) Map Administration and other support maps accrued from the Spatial Plan of the city of Pekanbaru, 2014-2034 [8], (3) Data DEM obtained from Bappeda Riau Province [9], evacuation of building area Data obtained from SIMAS (Mosque information system) which can be obtained on the website https://www simas.kemenag.go.id.

\subsection{Flood Modeling Simulation of Siak River}

Analysis of flood simulation modeling is conducted using Quantum GIS application 2.14.1 ESSEN (Q-GIS) using the iteration methods (see in Fig.2). 


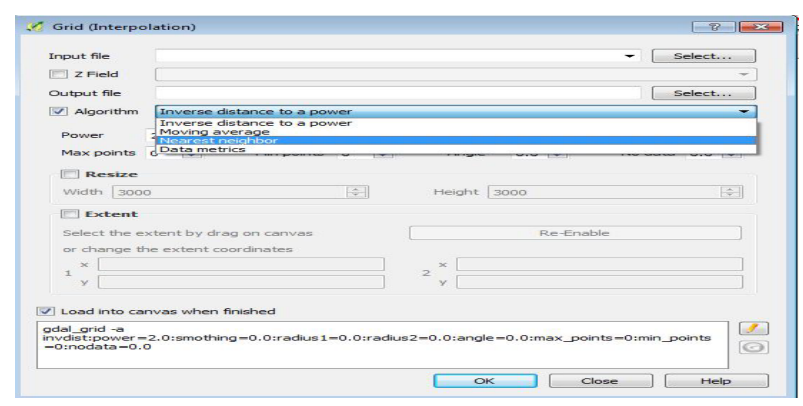

Fig.2. Display model of Q-GIS

Model simulation for the study prepared based on the maximum Flood inundation height results from the high index insecurity. In this regard, the inundation that occurred at the lowest altitude simulates a region on the DEM map. Fig. 3 shows how to get the lowest height from the data map DEM contour intervals.

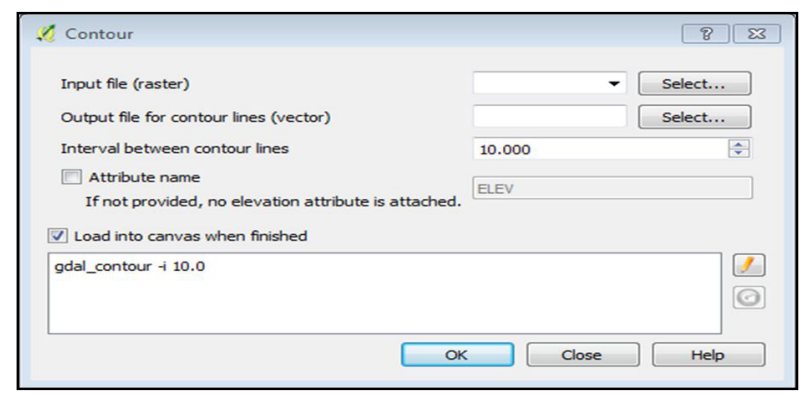

Fig.3. Display of Extract DEM of Q-GIS

\subsection{Determination of The Flood Evacuation Place}

The evacuation place capacity of the space required is determined based on a refugee, specifically $1 \mathrm{~m}^{2}$ (BAPPENAS). An evacuation place is chosen through a field survey by reviewing directly buildings that can be used. The figure shows Q-GI for bringing up public facilities using layer labeling settings (see in Fig.4).

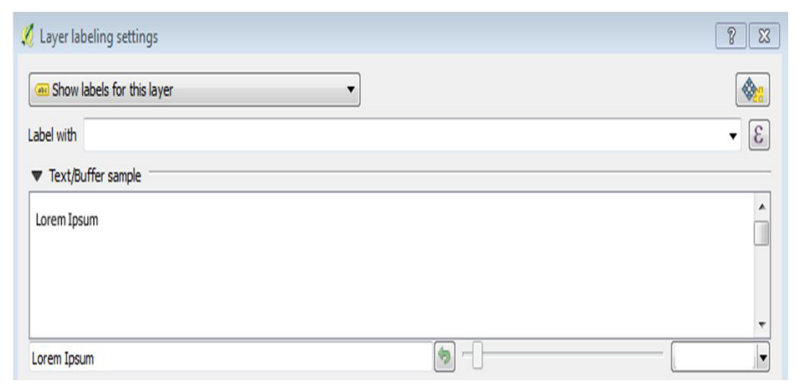

Fig.4. Display layer labeling setting Q-GIS.

\subsection{Determination of The Evacuation Line}

Analysis of road condition involves a survey conducted on a Subdistrict Rumbai with 6 (six) parameters, including long roads, flood simulation, the width of the road, road conditions, road surface, bridge location, and the direction of the road, as shown in Table 1.

All of the data parameters are given a score based on Table 1 before running Djikstra's algorithm method. Once all the road data network gives a score, each parameter is given different weights depending on their influence on the safety evacuation lines and speed, as shown in Table 2.

Table 1. Parameters of Evacuation Paths [5]

\begin{tabular}{|c|c|c|c|}
\hline No. & Classification & Class & Score \\
\hline \multirow[t]{5}{*}{1} & \multirow[t]{5}{*}{ Road Length (m) } & $<100$ & 20 \\
\hline & & $>=100-<200$ & 30 \\
\hline & & $>=200-<300$ & 40 \\
\hline & & $>=300-<400$ & 50 \\
\hline & & $>=400$ & 60 \\
\hline \multirow[t]{2}{*}{2} & \multirow[t]{2}{*}{ Flood Simulation } & Dangerous & 10000 \\
\hline & & Save & 20 \\
\hline \multirow[t]{5}{*}{3} & \multirow[t]{5}{*}{ Road Width (m) } & $<2$ & 100 \\
\hline & & $>2-<5$ & 50 \\
\hline & & $>=5-<7$ & 40 \\
\hline & & $>=7-<12$ & 30 \\
\hline & & $>=12$ & 20 \\
\hline \multirow[t]{3}{*}{4} & \multirow[t]{3}{*}{ Road Condition } & Good & 20 \\
\hline & & Enough & 30 \\
\hline & & Bad & 40 \\
\hline \multirow[t]{5}{*}{5} & \multirow{5}{*}{$\begin{array}{l}\text { Surface Road } \\
\text { Material }\end{array}$} & Asphalt & 20 \\
\hline & & Conblock & 30 \\
\hline & & Cement & 40 \\
\hline & & Rock & 60 \\
\hline & & Soil & 80 \\
\hline \multirow[t]{2}{*}{6} & \multirow[t]{2}{*}{ Bridge Location } & No Bridge & 20 \\
\hline & & Bridge & 30 \\
\hline \multirow[t]{2}{*}{7} & \multirow[t]{2}{*}{ Road Direction } & Two Way dir & 20 \\
\hline & & One Way dir & 30 \\
\hline
\end{tabular}

Table 2. The Evacuation Line Parameter Weights [5]

\begin{tabular}{|c|c|}
\hline Parameter of Evacuation Routes & Weights (\%) \\
\hline Flood Simulation & 30 \\
\hline Road Length & 25 \\
\hline Road Width & 15 \\
\hline Road Condition & 10 \\
\hline Surface Road Material & 9 \\
\hline Bridge Location & 7 \\
\hline Road Direction & 4 \\
\hline Total & 100 \\
\hline
\end{tabular}

\section{Result And Discussion}

\subsection{Flood Simulation Modelling of Siak River}

Modeling flood inundation simulation using the DEM map involves interpolating the data, changing them into a raster map. Fig.5 shows the values of the pixels of the height data. 
The flooded overflow is the scenario modeling on the maximum inundation elevation with insecurity index 0.5 $\mathrm{m}$ to $1.0 \mathrm{~m}$. The Genesis flood maximum is at the height of 1.0 meters. The existence of the modeling of the flood area is expected to help in the process of evacuation.

Based on Table 3, the flood inundation scenario's height is greater at the low elevation area, meaning the river's area is quite flat. The biggest impact is found in scenario $1 \mathrm{~m}$, covering an area of $6,777,826.16 \mathrm{~m}^{2}$. In comparison, the smallest impact is on $0.5 \mathrm{~m}$ scenarios, with a broad impact of 4,234,691.31 $\mathrm{m}^{2}$. Fig. 6 shows details about the results of the simulated flood overflow with various scenarios.
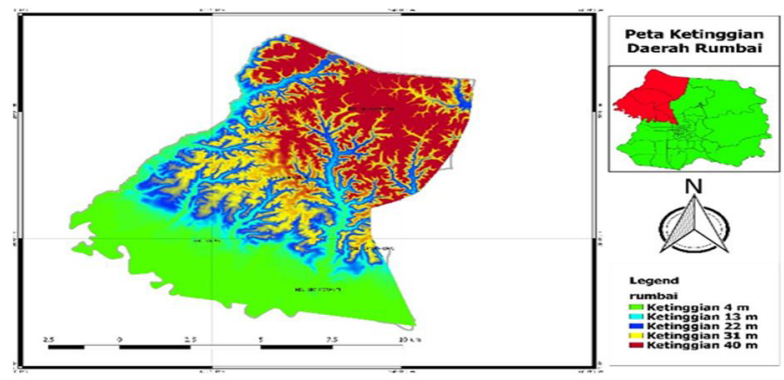

Fig.5. Raster DEM Map of Rumbai District.

Table 3. Impact of Widespread flooding from a Simulation Model

\begin{tabular}{|c|c|c|c|}
\hline No. & $\begin{array}{c}\text { The } \\
\text { scenario of } \\
\text { Flood } \\
\text { Height }(\mathrm{m})\end{array}$ & $\begin{array}{c}\text { Impact of } \\
\text { widespread } \\
\text { flooding }\left(\mathrm{m}^{2}\right)\end{array}$ & $\begin{array}{c}\text { Prosentase } \\
(\%)\end{array}$ \\
\hline 1 & 0.5 & $4,234,691.31$ & 38,45 \\
\hline \multirow[t]{2}{*}{2} & 1.0 & $6,777,826.16$ & 61,54 \\
\hline & Total & $11,012,517.47$ & $100 \%$ \\
\hline
\end{tabular}
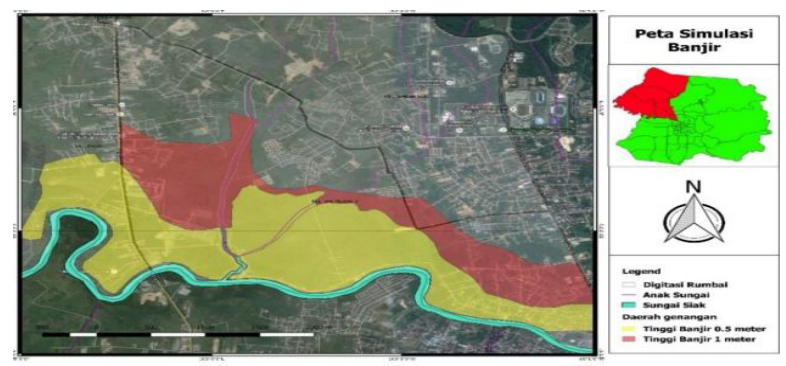

Fig.6. Map of the Inundation Simulation.

\subsection{Analysis of the Flood Evacuation Place}

The main purpose of evacuation is to move people from dangerous areas. An evacuation place selected should be a location safe from flooding. In general, a secure location for an evacuation should have elevation free of flooding, specifically permanent and non-permanent buildings. Permanent buildings can be in public facilities settled on the Tassel subdistrict, mosques, schools, and other public buildings. In comparison, non-permanent involve an empty land large enough to erect a building or evacuation tents. Table 4 shows the characteristics of a place that can be used as an evacuation place.
Table 4. Characteristics of Evacuation Place

\begin{tabular}{|c|c|c|c|}
\hline No & Building Type & $\begin{array}{c}\text { Location/ } \\
\text { Village }\end{array}$ & $\begin{array}{c}\text { Amount } \\
\text { of MCK }\end{array}$ \\
\hline$(1)$ & $(2)$ & $(3)$ & $(4)$ \\
\hline 1 & Al-Ikhlas mosque & Sri Meranti & 4 \\
\hline 2 & Aula MDA & Sri Meranti & 2 \\
\hline 3 & Nurul Haq mosque & Umban Sari & 4 \\
\hline 4 & Nurul Ukh mosque & Umban Sari & 4 \\
\hline 5 & Al-Jihad mosque & Palas & 4 \\
\hline 6 & Vacant Land & Umban Sari & - \\
\hline 7 & Stad Parking Area & Palas & - \\
\hline
\end{tabular}

\begin{tabular}{|c|c|c|c|}
\hline $\begin{array}{c}\text { Building } \\
\text { Area }\left(\mathbf{m}^{\mathbf{2}} \mathbf{)}\right.\end{array}$ & $\begin{array}{c}\text { Area } \\
\mathbf{( m}^{\mathbf{2}} \mathbf{)}\end{array}$ & $\begin{array}{c}\text { Amount of } \\
\text { Floor }\end{array}$ & Accessibility \\
\hline$(5)$ & $(6)$ & $(7)$ & $(8)$ \\
\hline 432 & 240 & 2 & Good \\
\hline 145 & 400 & 1 & Good \\
\hline 400 & 600 & 1 & Good \\
\hline 400 & 2,100 & 1 & Bad \\
\hline 400 & 500 & 1 & Good \\
\hline- & 650 & - & Good \\
\hline- & 6,000 & - & Good \\
\hline
\end{tabular}

\subsection{Analysis of Evacuation Path}

Table 5. The evacuation Line Route Division

\begin{tabular}{|c|c|c|c|}
\hline $\begin{array}{c}\text { Route of } \\
\text { Evacuation }\end{array}$ & $\begin{array}{c}\text { Collecting } \\
\text { Point }\end{array}$ & $\begin{array}{c}\text { Final } \\
\text { Point }\end{array}$ & $\begin{array}{c}\text { The building } \\
\text { of Evacuation } \\
\text { Place }\end{array}$ \\
\hline 1 & A & D & Al-Ikhlas Msq \\
\hline 2 & A & F & Aula MDA Rbi \\
\hline 3 & B & G & Empty Field \\
\hline 4 & B & E & $\begin{array}{c}\text { Nurul Haq } \\
\text { Msq }\end{array}$ \\
\hline 5 & B & H & $\begin{array}{c}\text { M Nurul } \\
\text { Mosque }\end{array}$ \\
\hline 6 & C & I & $\begin{array}{c}\text { Al-Jihad } \\
\text { Mosque }\end{array}$ \\
\hline 7 & B & J & $\begin{array}{c}\text { Stad Parking } \\
\text { area }\end{array}$ \\
\hline
\end{tabular}

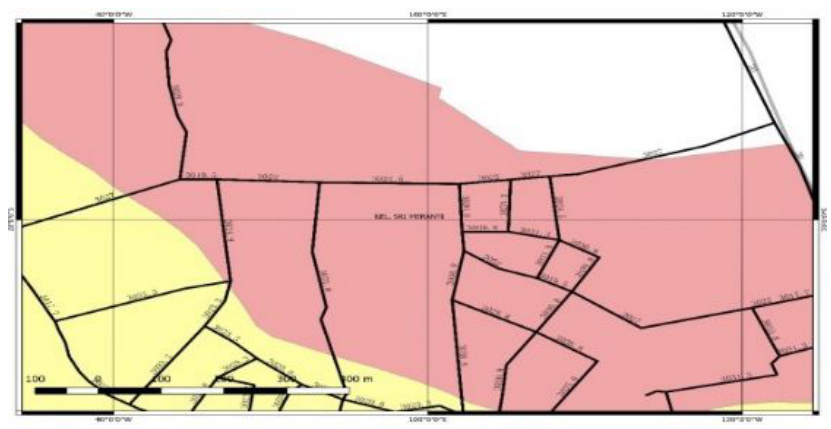

Fig.7. Weight of Road Segment 
Band selection is based on evacuation scoring results using the shortest path search method (Dijkstra's Algorithm). This method will essentially choose the lowest weight value and consider a score of weights for each parameter. Fig.7 shows the results of the weighting of each road segment based on the value set.

Table 5 shows the results of the analysis of evacuation line 7 with 3 points and 7 locations.

\subsubsection{Evacuation Line route 1}

A is the starting point located in the village of Sri, the gettogether point for the evacuation line route 1. Al-Ikhlas mosque is located at Yos Sudarso Street, the endpoint with the given symbol d. Each knot intersection or segment was given a symbol that denotes the node vertex of any route with a value or weights determined, as shown in Fig.8.

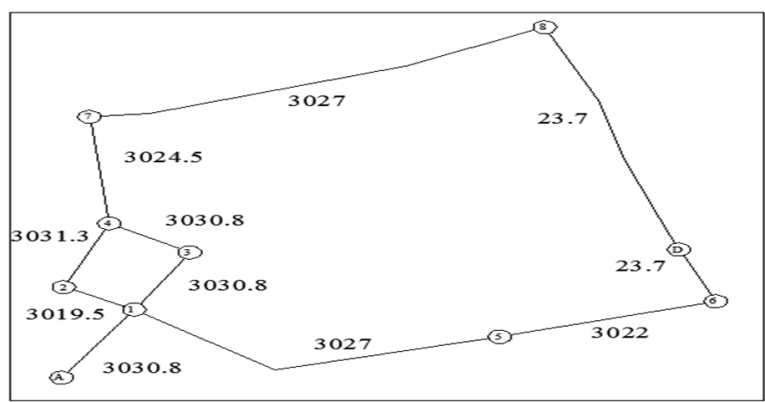

Fig.8. The determination of the Route 1

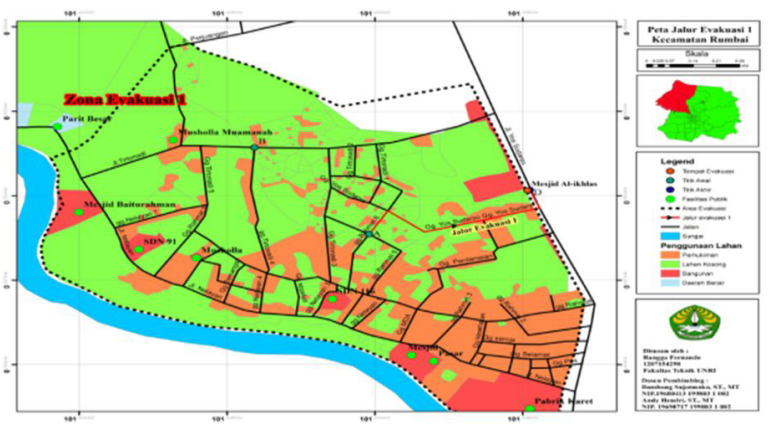

Fig.9. Evacuation Line route map 1

Table 6. The Lowest Weighting of the Route 1

\begin{tabular}{|c|c|c|c|}
\hline From & To & Shortest Route Path & Cost \\
\hline & 1 & A-1 & 3030.8 \\
\hline A & 2 & A-1-2 & 6050.3 \\
\hline A & 5 & A-1-5 & 6057.8 \\
\hline A & 3 & A-1-3 & 6061.6 \\
\hline A & 4 & A-1-2-4 & 9081.6 \\
\hline A & D & A-1-5-6-D & 9103.5 \\
\hline A & 7 & A-1-2-4-7 & 12106.1 \\
\hline
\end{tabular}

Fig. 8 shows each node route is analyzed through the algorithm djikstra. Table 6 shows the shortest route search using the algorithm djikstra method. Also, the table shows the determination of the evacuation line based on the smallest weights. The line selected evacuation routes for A starting point towards endpoint $\mathrm{D}$ is obtained through a combination of 9103.5 with a distance of 680 meters, passing through A routing node $\rightarrow 1 \rightarrow 5 \rightarrow 6 \rightarrow \mathrm{D}$ (Gg. Rahmat $6 \rightarrow \mathrm{Gg}$. Yos Sudarso $\rightarrow$ Yos Sudarso Street) as shown in Fig.9.

\subsubsection{Evacuation Line route 2}

A is the starting point located in the village of Sri. Part of it is the point of gathering for evacuation line route 2 to MDA Hall. It is located in the path of struggle, the endpoint with symbol f. Each knot intersection or segment was given a symbol that denotes the node verteks to any route with a value or weights determined, as shown in Fig. 10.

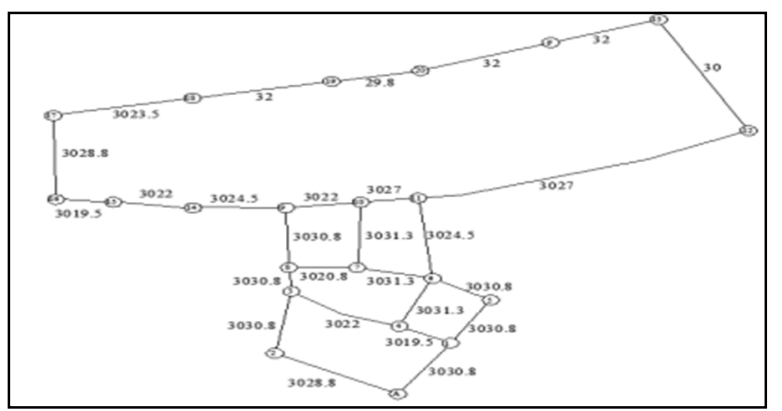

Fig.10. The determination of the Route 2

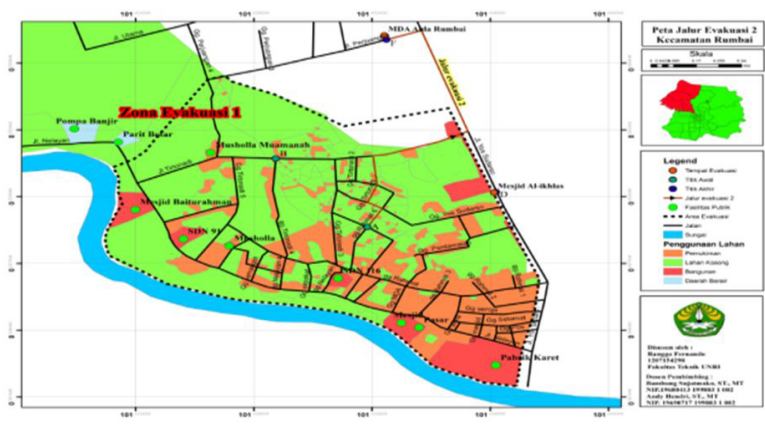

Fig.11. Evacuation Line route map 2.

According to Fig.10, each node route will be analyzed through the algorithm djikstra method. Table 7 shows the shortest route search results using this method and the determination of the evacuation line based on the smallest weights. The evacuation routes for A starting point towards the endpoint of the $\mathrm{F}$ line combinations are obtained with 15195.1 end weights and a distance of 1459 meters. It passes through A routing node $\rightarrow 1 \rightarrow 4 \rightarrow 6$ $\rightarrow 11 \rightarrow 12 \rightarrow 13 \rightarrow$ F (Gg. Grace $6 \rightarrow$ Gg. Bus $1 \rightarrow$ Bus St. $\rightarrow$ Yos Sudarso St. $\rightarrow$ Perjuangan St.), as shown in Fig. 11 .

Table 7. The Lowest Weighting of Route 2

\begin{tabular}{|c|c|c|c|}
\hline From & To & Shortest Route Path & Cost \\
\hline A & 2 & A-2 & 3028.8 \\
\hline A & 1 & A-1 & 3030.8 \\
\hline A & 6 & A-1-4-6 & 9081.6 \\
\hline A & 11 & A-1-4-6-11 & 12106.1 \\
\hline A & 13 & A-1-4-6-11-12-13 & 15163.1 \\
\hline A & F & A-1-4-6-11-12-13-F & 15195.1 \\
\hline A & 11 & A-2-3-8-7-10-11 & 18169.5 \\
\hline
\end{tabular}




\subsubsection{Evacuation Line route 3}

At the initial point B, located in the village of Sri, part of the gathering point for evacuation line Route 3, where on the goal line to evacuation is empty land, marked by an endpoint with symbol g. Each knot intersection or segment was given a symbol that denotes the node verteks to any route with a predetermined value or weights, as shown in Fig. 12.

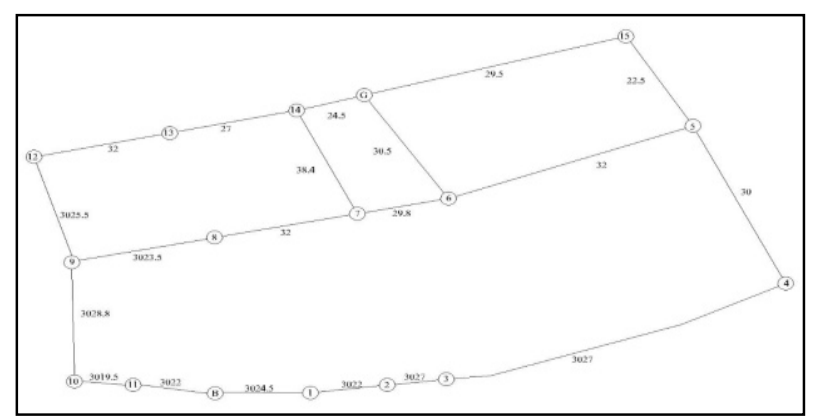

Fig.12. The determination of Route 3 .

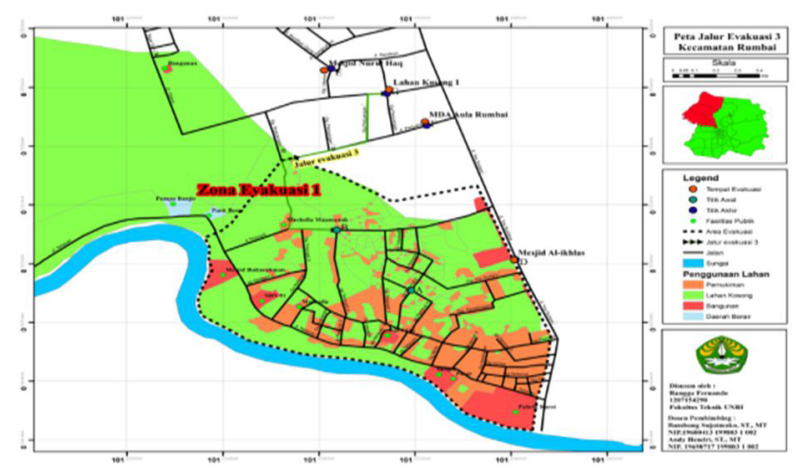

Fig.13. Evacuation Line route map 3

Table 8. The Lowest Weighting of Route 3

\begin{tabular}{|c|c|c|c|}
\hline From & To & Shortest Route Path & Cost \\
\hline B & 11 & B-11 & 3022.0 \\
\hline B & 1 & B-1 & 3024.5 \\
\hline B & 9 & B-11-10-9 & 9070.3 \\
\hline B & 3 & B-1-2-3 & 9073.5 \\
\hline B & 8 & B-11-10-9-8 & 12093.8 \\
\hline B & 14 & B-11-10-9-8-7-14 & 12150.3 \\
\hline B & G & B-11-10-9-8-7-14-G & 12174.8 \\
\hline B & 6 & B-11-10-9-8-7-6 & 12155.6 \\
\hline B & G & B-1-2-3-4-5-15-G & 12182.5 \\
\hline B & G & B-11-10-9-8-7-6-G & 12186.1 \\
\hline
\end{tabular}

In Fig.12, each node route is analyzed by the algorithm djikstra method. Table 8 shows the shortest route search obtained using this method and the determination of the evacuation line based on the smallest weights. The evacuation line starting from point $B$ towards the endpoint $\mathrm{G}$ was obtained by a combination of lines with weights of the end 12174.8 and a distance of 1383 meters, passing through the nodes route $\mathrm{B} \rightarrow 11 \rightarrow 10 \rightarrow 9 \rightarrow 8 \rightarrow 7 \rightarrow$ $14 \rightarrow$ G (Bus St. $\rightarrow$ Perjuangan St. $\rightarrow$ Gg. Struggle $2 \rightarrow$ Utama St.) as shown in Fig.13.

\subsubsection{Evacuation Line route 4}

The initial point B, located in the village of Sri, is the gettogether point for the evacuation line route 4 . It is on the goal line to the evacuation mosque Nurul Haq located in Gg Utama, the endpoint with symbol E. Each knot intersection or segment was given a symbol that denotes the node verteks any routes with a value or weights determined as shown in Fig.14.

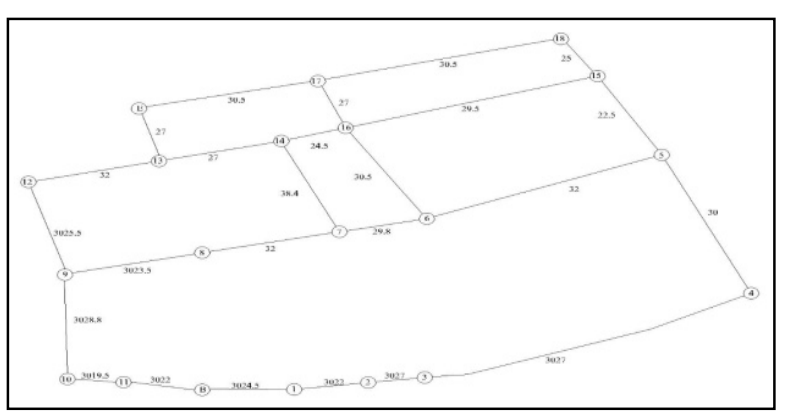

Fig.14. The determination of the Route 4

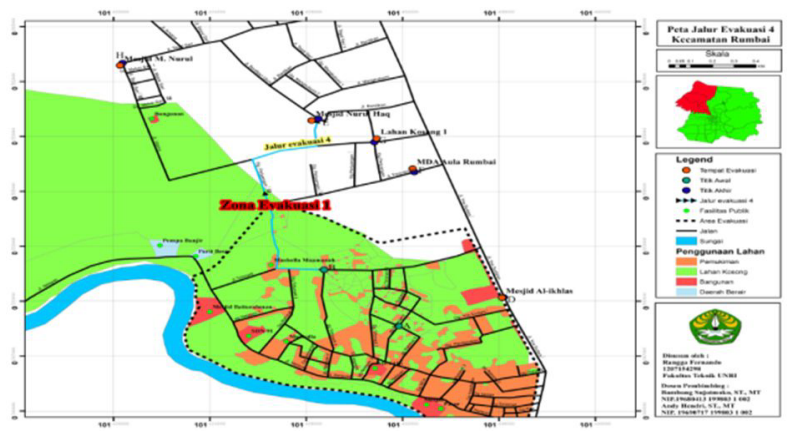

Fig.15. Evacuation Line route map 4

Table 9. The Lowest Weighting of Rute 4

\begin{tabular}{|c|c|c|c|}
\hline From & To & Shortest Route Path & Cost \\
\hline B & 11 & B-11 & 3022.0 \\
\hline B & 1 & B-1 & 3024.5 \\
\hline B & 2 & B-1-2 & 6046.5 \\
\hline B & 9 & B-11-10-9 & 9070.3 \\
\hline B & 3 & B-1-2-3 & 9073.5 \\
\hline B & 14 & B-11-10-9-8-7-14 & 12150.3 \\
\hline B & 15 & B-1-2-3-4-5-15 & 12153.0 \\
\hline B & E & B-11-10-9-12-13-E & 12154.8 \\
\hline B & 18 & B-1-2-3-4-5-15-18 & 12178.0 \\
\hline B & 6 & B-11-10-9-8-7-6 & 12155.6 \\
\hline
\end{tabular}

Fig.14 shows each node route is analyzed through the algorithm djikstra method. Table 9 shows the shortest route search results using this method and the determination of the evacuation line based on the smallest weights. The evacuation line selected starts from point B towards endpoint E. It is obtained through a combination line with 12154.8 end weight and a distance of 1378 meters, passing through the nodes route $\mathrm{B} \rightarrow 11 \rightarrow 10 \rightarrow$ $9 \rightarrow 12 \rightarrow 13 \rightarrow$ E (Bus St. $\rightarrow$ Perjuangan St. $\rightarrow$ Gg. Struggle $4 \rightarrow$ Utama St. $\rightarrow$ Gg. 2), as shown in Fig. 15 . 


\subsubsection{Evacuation Line route 5}

The initial point B, located in the village of Sri, is the gettogether point for the evacuation line route 5 to $\mathrm{M}$. Nurul mosque is located in Tegal Sari, which is the endpoint with the symbol h. Each knot intersection or segment was given a symbol that denotes the node verteks of any route with a value or weights determined. Fig. 16 shows more details.

According to Fig.16, each node route is analyzed through the algorithm djikstra method. Table 10 shows the shortest route search results using this method and the determination of the evacuation line based on the smallest weights. The evacuation line selected starts at point $\mathrm{B}$ towards the endpoint $\mathrm{H}$. It is obtained with the end of the line combination of 12348.2 with 1352 meters, where it passes through the nodes route $\mathrm{B} \rightarrow 11 \rightarrow 10 \rightarrow 9 \rightarrow 12$ $\rightarrow 13 \rightarrow 7 \rightarrow 8 \rightarrow 9 \rightarrow 10 \rightarrow 11 \rightarrow 24 \rightarrow 25 \rightarrow \mathrm{H}$ (Bus St. $\rightarrow$ Perjuangan St. $\rightarrow$ Gg. Struggle $4 \rightarrow$ Utama St. $\rightarrow$ Gg. $2 \rightarrow$ the way Achieve End $\rightarrow$ Tegal Sari), as shown in Fig. 17.

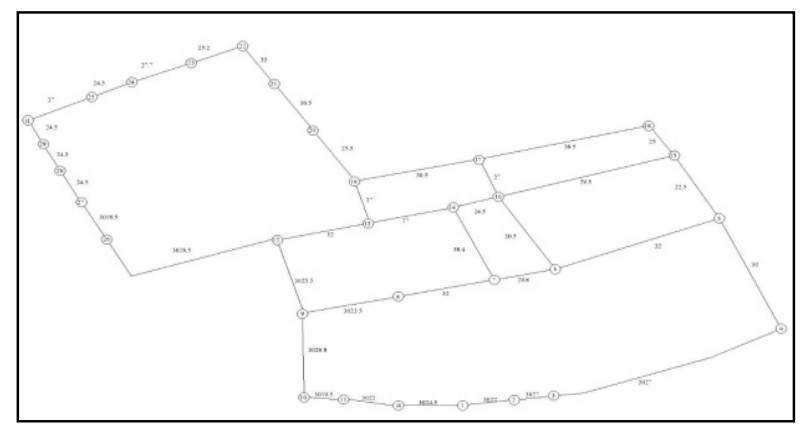

Fig.16. The determination of the Route 5

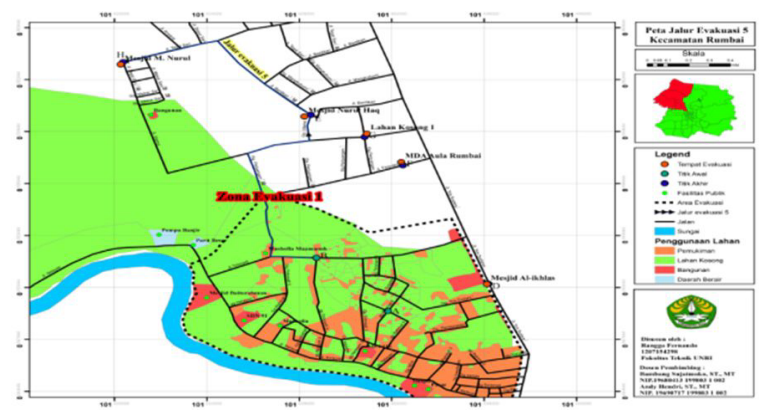

Fig.17. Evacuation Line route map 5

Table 10. The Lowest Weighting of Rute 5

\begin{tabular}{|c|c|c|c|}
\hline From & To & Shortest Route Path & Cost \\
\hline B & 11 & B-11 & 3022.0 \\
\hline B & 1 & B-1 & 3024.5 \\
\hline B & 10 & B-11-10 & 6041.5 \\
\hline B & 9 & B-11-10-9 & 9070.3 \\
\hline B & 6 & B-11-10-9-8-7-6 & 12155.6 \\
\hline B & 14 & B-11-10-9-8-7-14 & 12164.2 \\
\hline B & 22 & $\begin{array}{c}\text { B-11-10-9-12-13-19-20-21- } \\
22\end{array}$ & 12243.8 \\
\hline B & 25 & $\begin{array}{c}\text { B-11-10-9-12-13-19-20-21- } \\
22-23-24-25\end{array}$ & 12321.2 \\
\hline B & H & $\begin{array}{c}\text { B-11-10-9-12-13-19-20-21- } \\
24-25-H\end{array}$ & 12348.2 \\
\hline B & 26 & B-11-10-9-12-26 & 15124.3 \\
\hline
\end{tabular}

\subsubsection{Evacuation Line route 6}

The initial point $C$ is located at village Sri Meranti, the gathering point for evacuation lane route 6 at the goal line to Al-Jihad mosque. It is located on the Siak II, the endpoint with symbol i. Each knot intersection or segment was given a symbol that denotes the node verteks to any route with a value or weights determined, as shown in Fig.18.

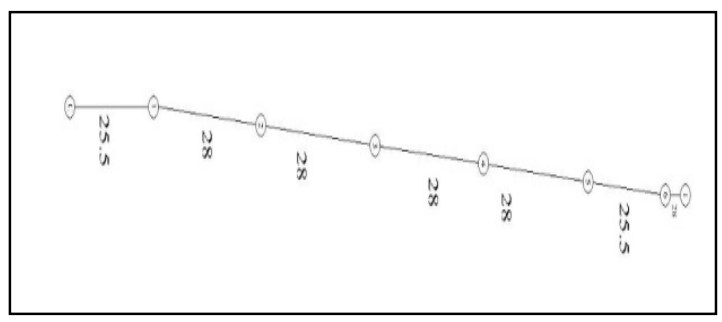

Fig.18. The determination of the Route 6

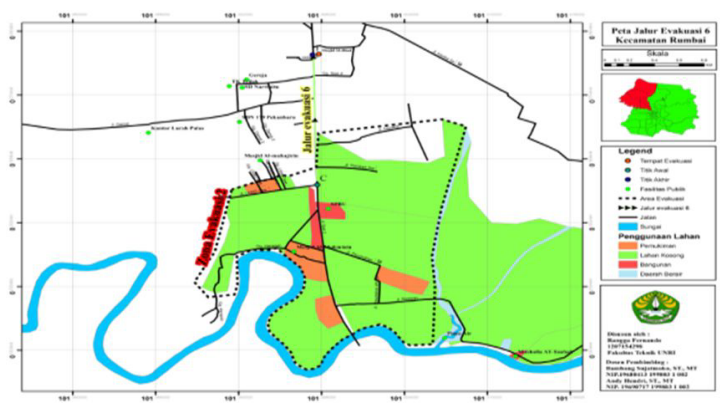

Fig.19. Evacuation Line route map 6

Fig.18 shows the evacuation line's determination directly specified because the path to the place of evacuation is not parallel. The evacuation line 6 passes through the Siak II with a distance of $1352 \mathrm{~m}$, as shown in Fig.19.

\subsubsection{Evacuation Line route 7}

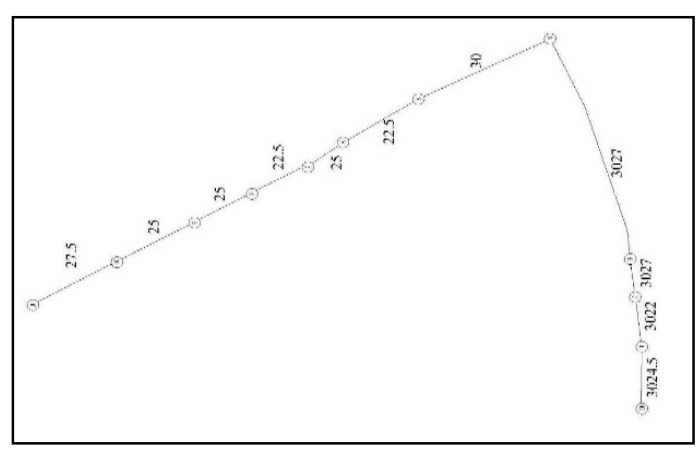

Fig. 20. The determination of the Route 7

The initial point B is located in the village of Sri, part of the gathering point for evacuation line Route 7 to the Stadium parking area. The site of evacuation tents is located at Yos Sudarso Street, the endpoint with symbol j. Evacuation Line 7 is directly determined through the Bus heading towards Yos Sudarso Street. This is because the evacuation path at point $\mathrm{B}$ towards the parking area 
has only two road routes. One of the routes has traversed two evacuation routes to avoid the build-up of mass on the line. It passes the 7 evacuation lines leading to the Yos Sudarso because the road is wide enough. Figure 21 shows the description of the evacuation line route 7 . Each node or segment intersection is given a symbol, which denotes any node verteks route with weights determined, as shown in Fig. 20.

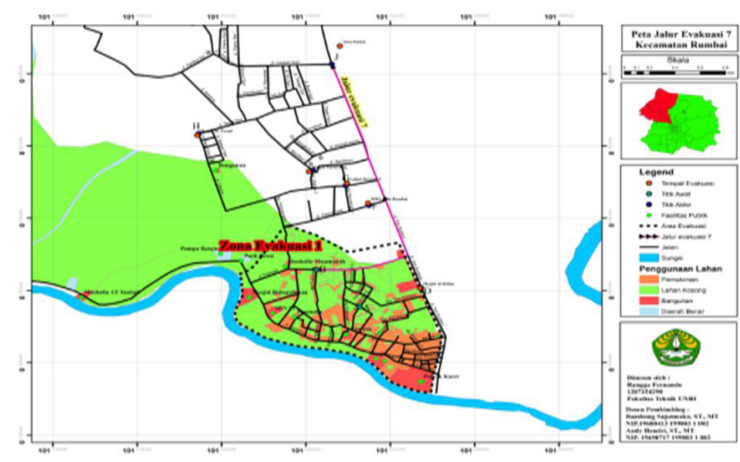

Fig. 21. Evacuation Line route map 7

\section{Conclusion}

Based on the analysis of the simulation of the flood, the sub-Tassel is extensively affected. The impact simulation on flood includes heights of 1 , specifically with an area of 677.78 ha. The vast height was 0.5 meters (half) 423.47 ha.

A total of 7 locations can be used as a place of evacuation with 5 permanent buildings and 2 (two) land locations for permanent and non-permanent building evacuation.

\section{References}

1. N D Suprayogi, Mapping of Inner City, Flood Vulnerable Areas, 257-262 (2015)

2. T. Afrizal, Increased Risk of Flood Disaster Due to overflow of Kali Kemuning in Sampang Regency Thesis Undergraduate Program (2013).

3. BNPB Guidelines for Preparation of Disaster Management Plans (Jakarta: National Disaster Management Agency) (2016)

4. Mei and Estuningtyas W Lessons Learned From The 2010 Evacuations At Merapi Volcano J. Volcanology And Geothermal Research, Volgeo-05104, 18 (2013)

5. S. Harsini, Geographical Information System Application (Solo: UNS) 1-15 (2014)

6. P. Eddy, Geographic Information System Basic Concepts (Geodesy and Geomatics Perspective) (Bandung: Informatics) (2009)

7. Central Bureau of Statistics General Condition of Pekanbaru City (Pekanbaru: BPS) (2003)

8. Pekanbaru City Spatial Planning Revised General Plan (Pekanbaru: Riswandi) (2004)

9. Bappeda Riau Province Area of Pekanbaru City by District (Pekanbaru: Riswandi) (2012)

10. BNPB Regulation of the Head of the National Disaster Management Agency (BNPB) No. 02 of 2012 (Jakarta: BNPB Office) (2012)

11. F. Ardini, Detrmination of the Shortest Distance and Alternative Shortest Distance Using the Dijkstra Algorithm and Travel Time Estimation of the National Seminar on Applied Information \& Communication Technology (2021) 